\title{
Synthesis and biological investigation of (+)-3-hydroxymethylartemisinin
}

\author{
Toni Smeilus ${ }^{1}$, Farnoush Mousavizadeh ${ }^{1}$, Johannes Krieger ${ }^{1}$, Xingzhao Tu$^{1}$, \\ Marcel Kaiser ${ }^{2,3}$ and Athanassios Giannis ${ }^{* 1}$
}

\author{
Full Research Paper \\ Address: \\ ${ }^{1}$ Faculty of Chemistry and Mineralogy, Institute of Organic Chemistry, \\ University of Leipzig, Johannisallee 29, 04301 Leipzig, Germany, \\ 2Dr. M. Kaiser Swiss Tropical and Public Health Institute, \\ Socinstrasse 57, 4051 Basel, Switzerland and ${ }^{3}$ University of Basel, \\ Petersplatz 1, 4003 Basel, Switzerland \\ Email: \\ Athanassios Giannis* - giannis@uni-leipzig.de \\ * Corresponding author \\ Keywords: \\ artemisinin; biomimetic synthesis; Diels-Alder reaction; malaria; \\ peroxides
}

Beilstein J. Org. Chem. 2019, 15, 567-570.

doi:10.3762/bjoc. 15.51

Received: 09 January 2019

Accepted: 20 February 2019

Published: 27 February 2019

Associate Editor: K. N. Allen

(c) 2019 Smeilus et al.; licensee Beilstein-Institut. License and terms: see end of document.

\begin{abstract}
Herein, we describe a biomimetic entry to (+)-3-hydroxymethylartemisinin (2) as well as to the artemisinin derivatives (+)-3-hydroxymethyl-9-desmethylartemisinin (16) and (+)-3-hydroxymethyl-9-epi-artemisinin (18), starting from the known and readily available chiral aldehyde 3 and alkyne 4 . Subsequently, the synthesized compounds have been evaluated for their antimalarial activity against the drug-sensitive $P$. falciparum NF54 strain. All of them were inactive. In addition, they did not show any toxicity against L6 cells (a primary cell line derived from rat skeletal myoblasts). These results contribute to a better understanding of artemisinins mechanism of action.
\end{abstract}

\section{Introduction}

The isolation of artemisinin (1; qinghaosu, Figure 1) from Artemisia annua $\mathrm{L}$. and the discovery of its antimalarial properties in 1971 represent one of the greatest medical breakthroughs of the 20th century [1,2]. For these achievements Youyou Tu was awarded the Nobel Prize in Physiology or Medicine in 2015 [3]. As artemisinin has poor solubility and bioavailability, several derivatives of this natural product like artesunate and artemether were developed and are currently used in combination with other drugs for the treatment of malaria [4]. However, the exact mechanism of action of this endoperoxide sesquiterpene lactone is still unknown [5].

Whereas artemisinins are almost non-toxic to normal cells, several studies have confirmed their potent antitumor activity $[6,7]$. In addition, they have been reported to possess immunosuppressive, anti-inflammatory, antiviral, antifungal and 


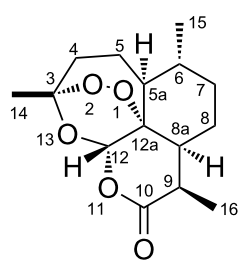

(+)-artemisinin (1)

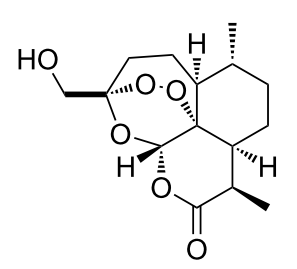

(+)-3-hydroxymethylartemisinin (2)
Figure 1: Structures of the natural (+)-artemisinin (1) and the synthesized (+)-3-hydroxymethylartemisinin (2).

antiparasitic activities [8-10]. Recently, it was shown that artemisinin interacts with the mammalian protein gephyrin and by stabilizing it, it enhances $\mathrm{GABA}_{\mathrm{A}}$ receptor signaling resulting in in vivo conversion of pancreatic $\alpha$-cells into functional $\beta$-like cells [11]. Therefore, this sesquiterpene lactone may also find an application in the treatment of diabetes mellitus. These facts indicate the clinical potential of artemisinins and "it is likely that artemisinin drugs will become a major armamentarium combating a variety of human diseases beyond malaria" [9].

In the past, several semi-synthetic artemisinin derivatives were prepared for experimental therapy of pathologies like the ones mentioned before $[12,13]$. However, the variety of these derivatives is limited as all of them are produced modifying the artemisinin skeleton at the same positions due to intrinsic synthetic challenges. Recently, we reported a biomimetic artemisinin synthesis that addresses these challenges and pave the way for derivatization of the (+)-artemisinin skeleton at positions not accessible using current methodology [14]. Based on our approach we report here on the synthesis and biological activity of the title compound (+)-3-hydroxymethylartemisinin (2 Figure 1).

\section{Results and Discussion}

Our synthesis (Scheme 1) started from the known and readily available aldehyde 3 [14] which was treated with the organolithium species obtained from derivative 4 [15] and $n$-BuLi to yield derivative 5. The latter afforded allylic alcohol $\mathbf{6}$ after reduction of the propargylic moiety with Red-Al. BAIB/ TEMPO oxidation of this alcohol gave ketone 7. By a Reformatsky reaction of $\mathbf{7}$ using $\mathrm{Zn}$ /ethyl bromoacetate derivative $\mathbf{8}$ was obtained, which was subjected to a thermal $\left(190{ }^{\circ} \mathrm{C}\right.$, toluene) intramolecular Diels-Alder reaction resulting in the formation of the $\beta$-hydroxy esters $\mathbf{9}, \mathbf{1 0}$ and $\mathbf{1 1}(\mathrm{dr}=1.74: 0: 38: 0.24)$ in a total yield of $84 \%$ (Scheme 2). Gratifyingly, the percentage of derivatives $\mathbf{9}$ and $\mathbf{1 0}$ that show the desired stereochemistry at carbon center $5 \mathrm{a}$ is around $90 \%$.

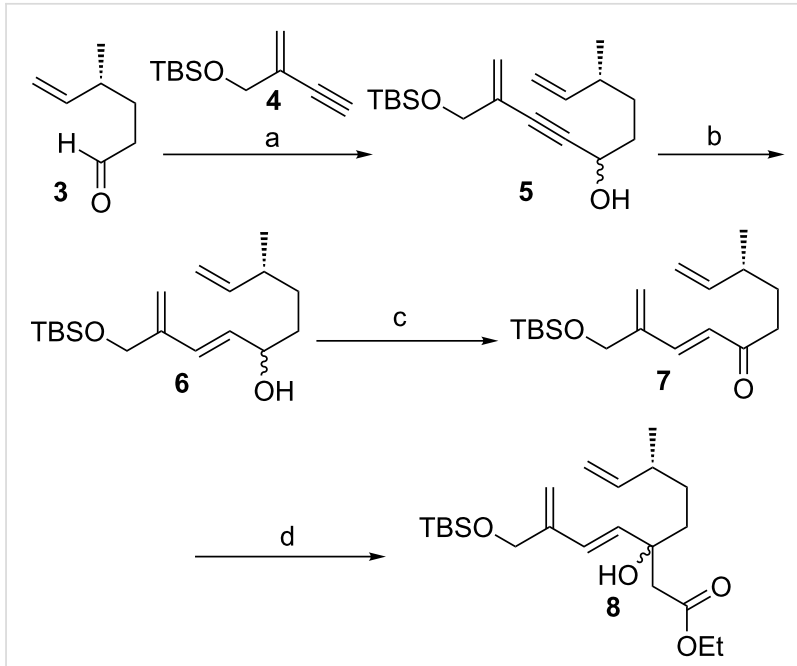

Scheme 1: Synthesis of the Diels-Alder precursor 8 over four steps in $71 \%$ yield, starting from aldehyde 3 and alkyne 4 . Reaction conditions: a) alkyne $4, n$-BuLi, THF, $-78{ }^{\circ} \mathrm{C}$ to rt, $16 \mathrm{~h}, 86 \%$; b) Red-Al, THF, $0{ }^{\circ} \mathrm{C}, 10 \mathrm{~min}, 96 \%$; c) BAIB, TEMPO, DCM, rt, $16 \mathrm{~h}, 92 \%$; d) $\mathrm{BrCH}_{2} \mathrm{CO}_{2} \mathrm{Et}$, $\mathrm{Zn}$, toluene, reflux, $30 \mathrm{~min}, 93 \%$. Red-Al = sodium bis(2-methoxyethoxy)aluminum dihydride, BAIB = (diacetoxyiodo)benzene, TEMPO = (2,2,6,6-tetramethylpiperidin-1-yl)oxyl.

The structure of all these isomers was confirmed by NOE experiments (see Supporting Information File 1 for full experimental details). Both derivatives 9 and $\mathbf{1 0}$ (Scheme 2) yielded $\alpha, \beta$-unsaturated esters $\mathbf{1 2}$ and $\mathbf{1 3}$ after treatment with Martin sulfurane [16]. Reduction of compound 12 using $\mathrm{NiCl}_{2} / \mathrm{NaBH}_{4}$ in methanol as solvent yielded derivative $\mathbf{1 4}$ with excellent diastereomeric ratio $(\mathrm{dr}=1: 0.03)$. On the other hand, derivative $\mathbf{1 3}$ was reduced under Birch conditions $\left(\mathrm{Li} / \mathrm{NH}_{3}\right)$ to afford ester 15 in $61 \%$ yield $(\mathrm{dr}=1: 0.4)$. Gratifyingly, both artemisinin precursors 14 and 15 possess the desired stereoconfiguration at carbon center $8 \mathrm{a}$.

Subsequently, a solution of $\mathbf{1 4}$ and $\mathbf{1 5}$ in dichloromethane containing methylene blue as photosensitizer was exposed to sunlight and oxygen. The treatment of the resulting intermediate hydroperoxide with a small amount of trifluoroacetic acid as previously described $[17,18]$, afforded in the frame of a Hock cleavage (+)-3-hydroxymethyl-9-desmethylartemisinin (16) in $24 \%$ and $16 \%$ yield, respectively. Protection of the free hydroxy group of $\mathbf{1 6}$ as a silyl ether and methylation of the obtained lactone in $\alpha$-position (LDA/MeI/HMPA) afforded derivative 17. After removal of the TES protecting group (+)-3-hydroxymethyl-9-epi-artemisinin (18, Scheme 3) was obtained, whereas the desired (+)-3-hydroxymethylartemisinin (2) was produced from 17 in two steps including epimerization and cleavage of the TES group in excellent yield (Scheme 3 ).

Finally, we evaluated the antimalarial activity of (+)-3-hydroxymethylartemisinin (2) as well as of the derivatives $\mathbf{1 6}$ and $\mathbf{1 8}$ 


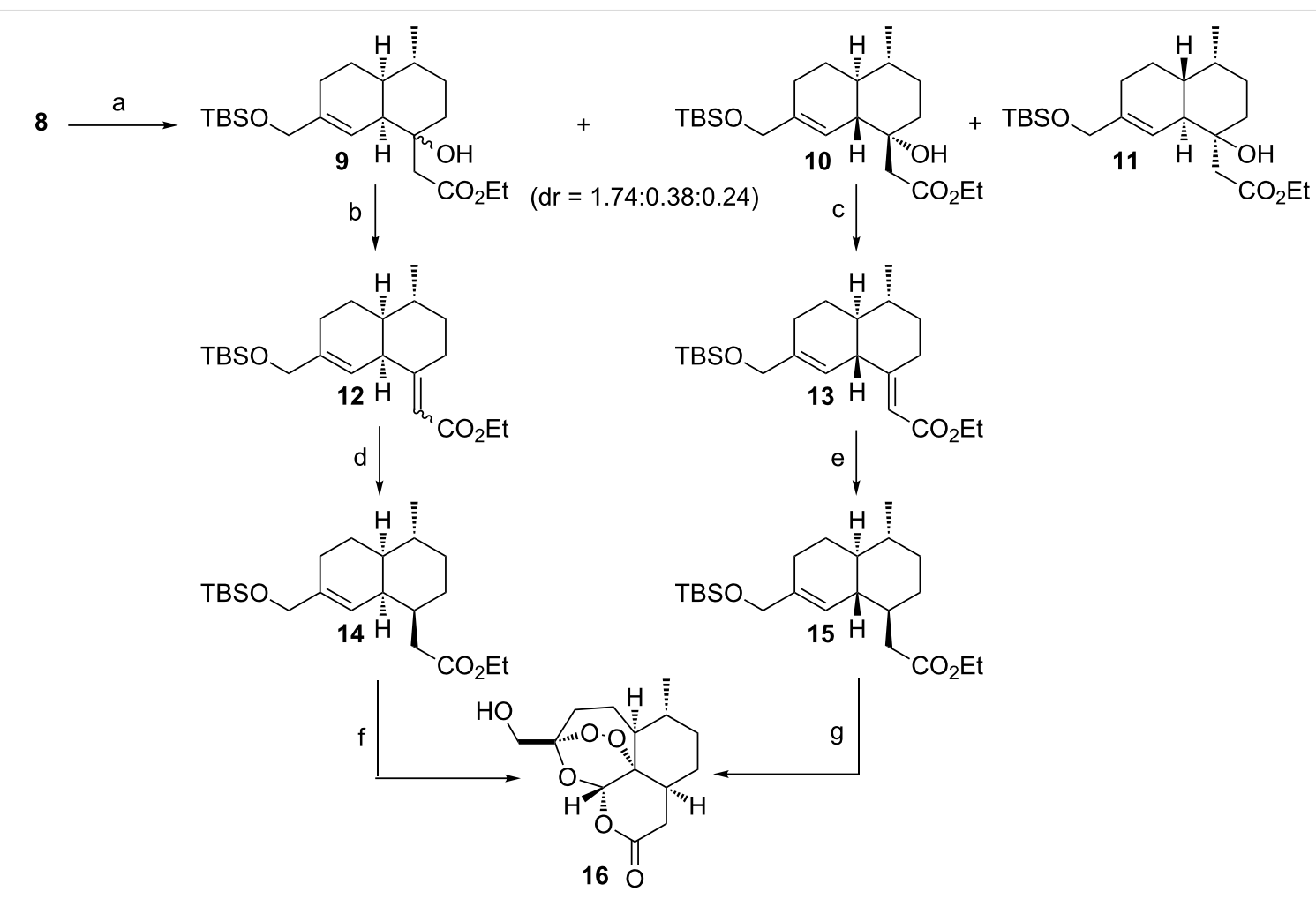

Scheme 2: Synthesis of (+)-3-hydroxymethyl-9-desmethylartemisinin (16), starting from Diels-Alder derivatives 9 and 10. Reaction conditions: a) toluene, $190{ }^{\circ} \mathrm{C}, 24 \mathrm{~h}, 84 \%$ (dr 9:10:11 = 1.74:0.38:0.24); b) Martin sulfurane, DCM, $0^{\circ} \mathrm{C}, 10 \mathrm{~min}, 97 \%[(E) /(Z)=1: 1]$; $\left.\mathrm{c}\right) \mathrm{Martin}$ sulfurane, DCM, $0{ }^{\circ} \mathrm{C}$, $10 \mathrm{~min}, 95 \%$; d) $\mathrm{NiCl}_{2}, \mathrm{NaBH}_{4},-60{ }^{\circ} \mathrm{C}$ to $-40{ }^{\circ} \mathrm{C}, 1 \mathrm{~h}, 96 \%$ (dr = 1:0.03); e) $\mathrm{Li}$, EtOH, $\mathrm{NH}_{3},-70{ }^{\circ} \mathrm{C}, 10 \mathrm{~min}, 61 \%$ (dr = 1:0.4); f) i. O light, DCM, $-30{ }^{\circ} \mathrm{C}, 30 \mathrm{~h}$; ii. then $\mathrm{O}_{2}$, cat. TFA, DCM, rt, 2 d, $24 \%$; g) i. $\mathrm{O}_{2}$, methylene blue, light, DCM, $-30{ }^{\circ} \mathrm{C}, 30 \mathrm{~h}$; ii. then $\mathrm{O}_{2}$, cat. TFA, DCM, rt, $2 \mathrm{~d}, 16 \%$ [13].

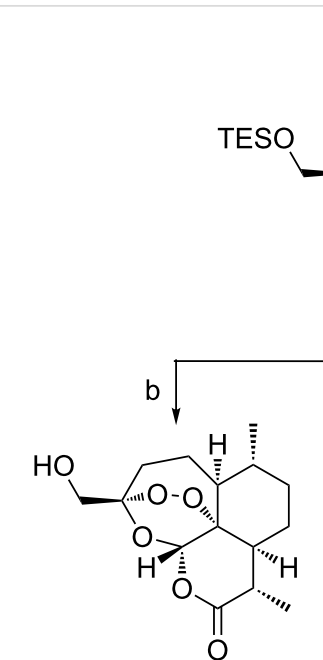

(+)-3-hydroxymethyl-

9-epi-artemisinin (18) against the drug-sensitive $P$. falciparum NF54 strain as described previously [14]. We found them to be inactive. In addition, 2 did not show any toxicity against L6 cells (a primary cell line derived from rat skeletal myoblasts). In both assays the highest concentration used was $100 \mu \mathrm{g} / \mathrm{mL}$.

\section{Conclusion}

In the past it has been postulated that artemisinins kill intraerythrocytic parasites such as $P$. falciparum in the presence of $\mathrm{Fe}^{2+}$ forming reactive oxygen species (ROS) [4]. As artemisinin and similar derivatives are destroyed by $\mathrm{Fe}^{2+}$ in vitro (Fenton reaction), it is difficult for us to explain their inactivity against Plasmodium. Furthermore, in cellular systems free ferrous iron [19] as well as haem [20,21] have been proposed to be the main iron sources for artemisinin activation. However, the results on that matter remain controversial $[4,22]$. Our results challenge the radical hypothesis of artemisinins action and also indicate that the methyl group at the C-3 position of artemisinin is possibly involved in lipophilic interactions with putative proteins essential for survival of the Plasmodium parasite. Derivative $\mathbf{2}$ will be used to attach further substituents at position 14 of artemisinin to prove this hypothesis.
Scheme 3: Synthesis of (+)-3-hydroxymethyl-9-epi-artemisinin (18) and (+)-3-hydroxymethylartemisinin (2). Reaction conditions: a) i. TESCl, $\mathrm{NEt}_{3}, 0{ }^{\circ} \mathrm{C}, 16 \mathrm{~h}$; ii. LDA, Mel, HMPA, THF, $-78{ }^{\circ} \mathrm{C}$ to $-50{ }^{\circ} \mathrm{C}, 1 \mathrm{~h}, 73 \%$ (over two steps); b) TBAF, THF, $0{ }^{\circ} \mathrm{C}, 10 \mathrm{~min}, 95 \%$; c) i. DBU, DCM, rt, $1 \mathrm{~d}$; ii. TBAF, THF, $0^{\circ} \mathrm{C}, 10 \mathrm{~min}, 87 \%$ (over two steps). $\mathrm{LDA}=$ lithium diisopropylamide, HMPA = hexamethylphosphoramide, $\mathrm{DBU}=1$,8-diazabicyclo[5.4.0]undec-7-ene, $\mathrm{TESCl}=$ triethylsilyl chloride. 


\section{Experimental}

Experimental details, NMR spectra and other physical data are shown in Supporting Information File 1.

\section{Supporting Information}

\section{Supporting Information File 1}

Experimental part.

[https://www.beilstein-journals.org/bjoc/content/

supplementary/1860-5397-15-51-S1.pdf]

\section{ORCID®iDs}

Athanassios Giannis - https://orcid.org/0000-0003-2203-0959

\section{References}

1. White, N. J. Science 2008, 320, 330-334 doi:10.1126/science.1155165

2. White, N. J.; Hien, T. T.; Nosten, F. H. Trends Parasitol. 2015, 31, 607-610. doi:10.1016/j.pt.2015.10.010

3. Tu, Y. Angew. Chem., Int. Ed. 2016, 55, 10210-10226. doi:10.1002/anie.201601967 Angew. Chem. 2016, 128, 10366-10382. doi:10.1002/ange.201601967

4. Phillips, M. A.; Burrows, J. N.; Manyando, C.; van Huijsduijnen, R. H.; Van Voorhis, W. C.; Wells, T. N. C. Nat. Rev. Dis. Primers 2017, 3, 17050. doi:10.1038/nrdp.2017.50

5. Wang, J.; Zhang, C.-J.; Chia, W. N.; Loh, C. C. Y.; Li, Z.; Lee, Y. M.; He, Y.; Yuan, L.-X.; Lim, T. K.; Liu, M.; Liew, C. X.; Lee, Y. Q.; Zhang, J.; Lu, N.; Lim, C. T.; Hua, Z.-C.; Liu, B.; Shen, H.-M.; Tan, K. S. W.; Lin, Q. Nat. Commun. 2015, 6, 10111. doi:10.1038/ncomms10111

6. Krishna, S.; Ganapathi, S.; Ster, I. C.; Saeed, M. E. M.; Cowan, M.; Finlayson, C.; Kovacsevics, H.; Jansen, H.; Kremsner, P. G.; Efferth, T.; Kumar, D. EBioMedicine 2015, 2, 82-90. doi:10.1016/j.ebiom.2014.11.010

7. Ericsson, T.; Blank, A.; von Hagens, C.; Ashton, M.; Äbelö, A. Eur. J. Clin. Pharmacol. 2014, 70, 1453-1463. doi:10.1007/s00228-014-1754-2

8. Raffetin, A.; Bruneel, F.; Roussel, C.; Thellier, M.; Buffet, P.; Caumes, E.; Jauréguiberry, S. Med. Mal. Infect. 2018, 48, 238-249. doi:10.1016/j.medmal.2018.01.004

9. Krishna, S.; Bustamante, L.; Haynes, R. K.; Staines, H. M. Trends Pharmacol. Sci. 2008, 29, 520-527. doi:10.1016/j.tips.2008.07.004

10. Ho, W. E.; Peh, H. Y.; Chan, T. K.; Wong, W. S. F. Pharmacol. Ther. 2014, 142, 126-139. doi:10.1016/j.pharmthera.2013.12.001

11. Li, J.; Casteels, T.; Frogne, T.; Ingvorsen, C.; Honoré, C.; Courtney, M.; Huber, K. V. M.; Schmitner, N.; Kimmel, R. A.; Romanov, R. A.; Sturtzel, C.; Lardeau, C.-H.; Klughammer, J.; Farlik, M.; Sdelci, S.; Vieira, A.; Avolio, F.; Briand, F.; Baburin, I.; Májek, P.; Pauler, F. M.; Penz, T.; Stukalov, A.; Gridling, M.; Parapatics, K.; Barbieux, C.; Berishvili, E.; Spittler, A.; Colinge, J.; Bennett, K. L.; Hering, S.; Sulpice, T.; Bock, C.; Distel, M.; Harkany, T.; Meyer, D.; Superti-Furga, G.; Collombat, P.; Hecksher-Sørensen, J.; Kubicek, S Cell 2017, 168, 86-100. doi:10.1016/j.cell.2016.11.010

12. Njuguna, N. M.; Ongarora, D. S. B.; Chibale, K. Expert Opin. Ther. Pat. 2012, 22, 1179-1203. doi:10.1517/13543776.2012.724063
13. Mao, W.; Zhang, Y.; Zhang, A. Discovery of Antimalarial Drug Artemisinin and Beyond. In Case Studies in Modern Drug Discovery and Development; Huang, X.; Aslanian, R. G., Eds.; John Wiley \& Sons: Hoboken, NJ, U.S.A., 2012; pp 227-256. doi:10.1002/9781118219683.ch10

14. Krieger, J.; Smeilus, T.; Kaiser, M.; Seo, E.-J.; Efferth, T.; Giannis, A. Angew. Chem., Int. Ed. 2018, 57, 8293-8296.

doi:10.1002/anie.201802015

Angew. Chem. 2018, 130, 8425-8428. doi:10.1002/ange.201802015

15. Charpenay, M.; Boudhar, A.; Hulot, C.; Blond, G.; Suffert, J. Tetrahedron 2013, 69, 7568-7591. doi:10.1016/j.tet.2013.05.089

16. Martin, J. C.; Arhart, R. J. J. Am. Chem. Soc. 1971, 93, 4327-4329. doi:10.1021/ja00746a059

17. Lévesque, F.; Seeberger, P. H. Angew. Chem., Int. Ed. 2012, 51, 1706-1709. doi:10.1002/anie.201107446 Angew. Chem. 2012, 124, 1738-1741. doi:10.1002/ange.201107446

18. Acton, N.; Roth, R. J. J. Org. Chem. 1992, 57, 3610-3614. doi:10.1021/jo00039a020

19. Stocks, P. A.; Bray, P. G.; Barton, V. E.; Al-Helal, M.; Jones, M.; Araujo, N. C.; Gibbons, P.; Ward, S. A.; Hughes, R. H.; Biagini, G. A.; Davies, J.; Amewu, R.; Mercer, A. E.; Ellis, G.; O'Neill, P. M. Angew. Chem., Int. Ed. 2007, 46, 6278-6283. doi:10.1002/anie.200604697

20. Klonis, N.; Crespo-Ortiz, M. P.; Bottova, I.; Abu-Bakar, N.; Kenny, S.; Rosenthal, P. J.; Tilley, L. Proc. Natl. Acad. Sci. U. S. A. 2011, 108, 11405-11410. doi:10.1073/pnas.1104063108

21. Robert, A.; Benoit-Vical, F.; Claparols, C.; Meunier, B. Proc. Natl. Acad. Sci. U. S. A. 2005, 102, 13676-13680. doi:10.1073/pnas.0500972102

22. Haynes, R. K.; Krishna, S. Microbes Infect. 2004, 6, 1339-1346. doi:10.1016/j.micinf.2004.09.002

\section{License and Terms}

This is an Open Access article under the terms of the Creative Commons Attribution License (http://creativecommons.org/licenses/by/4.0). Please note that the reuse, redistribution and reproduction in particular requires that the authors and source are credited.

The license is subject to the Beilstein Journal of Organic Chemistry terms and conditions: (https://www.beilstein-journals.org/bjoc)

The definitive version of this article is the electronic one which can be found at: doi:10.3762/bjoc. 15.51 